\title{
EVALUATION OF CURRENT EGYPTIAN CODE ON SEISMIC BEHAVIOR OF MULTI-STOREY BUILDINGS
}

\author{
M. N. Mohamed ${ }^{1,}$, F.K Abdel Sayed ${ }^{2}$, Shehata. E. Abdel Reheem ${ }^{3}$, \\ Ahmed Abdel Reheem Farghly ${ }^{4}$ and Ashraf A. Mohamed \\ ${ }^{1}$ Technical Marketing Manager, CEMEX Company \\ 2, 3, 5 Staff in Civil Eng. Dep., Faculty of Engineering, Assiut University, Assiut, Egypt. \\ ${ }^{4}$ Civil and Architectural Constructions Dep. Industrial Education College, Sohag University, Sohag, Egypt
}

Received 14 July 2013; accepted 3 August 2013

\begin{abstract}
This research presents an investigation through a numerical study on the effect of two parameters; stiffness of columns and number of stories on both base shear force and top displacement of buildings. In this study, two dimensional models were used with varying number of stories $(6,12$, 20 and 30) and varying column cross sections. The results proved that these two parameters have significant impact on both base shear and top displacements. Results show a difference between actual seismic behavior and the resulted seismic behavior from traditional code method, which reflects on economic designs of such structures.
\end{abstract}

\section{Introduction}

An earthquake is defined, from a structural point of view, as a dynamic displacement of the ground supporting a structure, resulting in structure vibration and consequently dynamic earthquake loading [1],[5].

Severe damage of buildings is the most distressing consequence of earthquakes. In the last 20 years, Egypt was struck by many earthquakes. It resulted in hundreds killed and injured; also it incurred an economic loss.

The purpose of building codes is to promote and protect the public welfare, as well as the economic well-being of the community as a whole. Egyptian Code 201/2008 introduce an equation to be used for calculating base shear depending on earthquake activity zone, fundamental period of the building and own weight regardless the stiffnesses of columns. A previous research [3] studied the effect of concrete cracking of structural elements (columns and beams) on the seismic lateral response of structures.

The Egyptian code neglects totally the column stiffness effect in the introduced equations in spite of its considerable influence on estimating the base shear and top displacements. It is strongly recommended to take both column stiffness and actual number of stories effect into consideration in the future edits of the code.

Theoretical background and Literature Review:

Egyptian code states the below equation to calculate the ultimate base shear force [2],

$$
\mathrm{Fb}=\mathrm{Sd}(\mathrm{T} 1)^{\lambda} \mathrm{W} / \mathrm{g}
$$

Where:

$\mathrm{Fb}$ : Ultimate base shear force

\footnotetext{
* Corresponding author.

E-mail address:
} 
M. N. Mohamed, et al., Evaluation of Current Egyptian Code on Seismic Behavior of Multi-Storey Buildings, pp. 1743 - 1752

$\mathrm{Sd}$ (T1): Design spectrum for elastic analysis at $\mathrm{T}=\mathrm{T} 1$, it depends mainly on Earthquake zone, the importance of the building, the structural system and building material.

T1: Fundamental period of the building, it depends on building total height starting above the foundation level, the structural system and material.

$\lambda$ : Correction factor, which can be calculated as follows:

$$
\begin{array}{llrlrl}
\lambda=0.85 & \text { if } & T 1 \leq_{2 \mathrm{TC}} \\
\lambda=1.0 & \text { if } & T 1>_{2 \mathrm{TC}}
\end{array}
$$

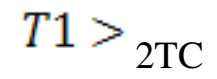

Where:

TC : Constant value limits of elastic response spectrum, its value depends on subsoil class.

$\mathrm{W}$ : Total weight of the structure (above ground surface)

$\mathrm{g}$ : Ground gravity acceleration $=981 \mathrm{~cm} / \mathrm{sec} 2$

Distribution of horizontal earthquake forces [2]:

$F i=\left[\frac{z i * W i}{\sum_{j=1, n} z j * W j}\right] * F b$

$F i$

: Horizontal earthquake force at floor level (i)

$z i$, : The heights of floors number $\mathrm{i}, \mathrm{j}$ measured from top foundation level

$W i$, : The design weight of floors number $\mathrm{i}, \mathrm{j}$

$F b$ : Ultimate base shear force

From equations (1) and (2), it is clearly noticed that the columns stiffnesses were not taken into consideration.

\section{Methodology}

Symmetric multistory buildings have been studied under an earthquake loading. These investigated models, have been analyzed using SAP2000 "Structural Analysis Program".

Two methods were used in this research, the traditional method that is accredited by Egyptian code (201/2008) and time history method, in purpose of clarifying the actual effect of two parameters;
A - Columns stiffnesses
B -Number of stories

\section{Modeling}

To study the effect of both columns stiffness and number of stories on base shear and top displacements, four symmetric two dimensional models with fixed base and varying number of stories were analyzed by SAP 2000 program. Models details are as follows:

- Number of spans $=2$, each span $=4 \mathrm{~m}$.

- Number of stories $=6,12,20$ and 30 .

- Story height $=3.0 \mathrm{~m}$ (fixed for all floors in all cases).

Journal of Engineering Sciences, Assiut University, Faculty of Engineering, Vol. 41, No. 5, September, 2013, E-mail address: jes@aun.edu.eg 
M. N. Mohamed, et al., Evaluation of Current Egyptian Code on Seismic Behavior of Multi-Storey Buildings, pp. 1743 - 1752

- Beams cross section $=0.25 * 0.60 \mathrm{~m}$ (fixed for all beams in all cases).

- Modulus of elasticity, $\mathrm{E}=253.5$ ton $/ \mathrm{cm}^{2}$

- The used columns cross sections were fixed in all the models columns.

- The used columns cross sections and moments of inertia were indicated in table 1.

Table 1.

Columns sections and moments of inertia

\begin{tabular}{|c|c|}
\hline Column Cross Section (cm) & Moment of Inertia $\mathbf{I}_{\mathbf{y}}\left(\mathbf{c m}^{\mathbf{4}}\right)$ \\
\hline $25 * 50$ & $6.51 \mathrm{E}+04$ \\
\hline $25 * 75$ & $9.77 \mathrm{E}+04$ \\
\hline $25 * 100$ & $1.30 \mathrm{E}+05$ \\
\hline $25 * 125$ & $1.63 \mathrm{E}+05$ \\
\hline $25 * 150$ & $1.95 \mathrm{E}+05$ \\
\hline
\end{tabular}

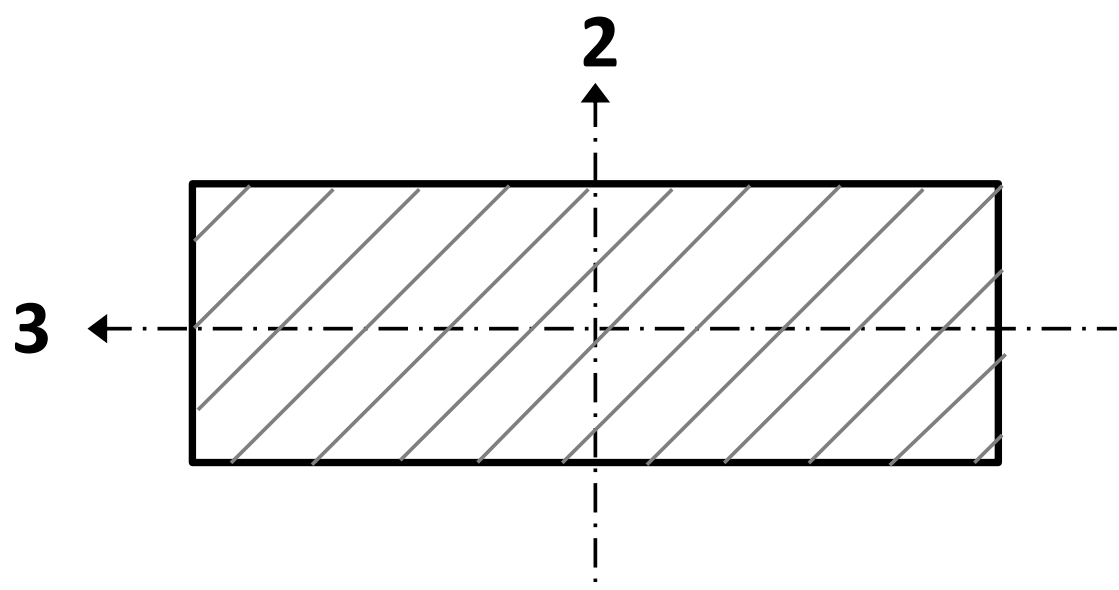

Fig. 1. Column direction

Regarding to code traditional method, it is assumed that the soil is medium (subsoil class C) and elastic response spectrum is curve type number 1 (this curve is used for all Egypt zones).

Fig. 2, illustrates the geometry and dimensions of the four models.

Journal of Engineering Sciences, Assiut University, Faculty of Engineering, Vol. 41, No. 5, September, 2013,E-mail address: jes@aun.edu.eg 
M. N. Mohamed, et al., Evaluation of Current Egyptian Code on Seismic Behavior of Multi-Storey Buildings, pp. 1743 - 1752

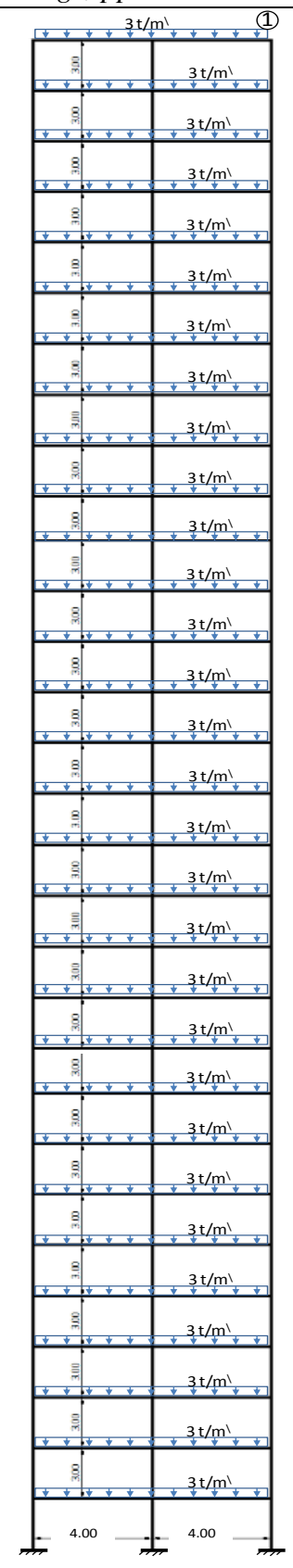

30 -stories model

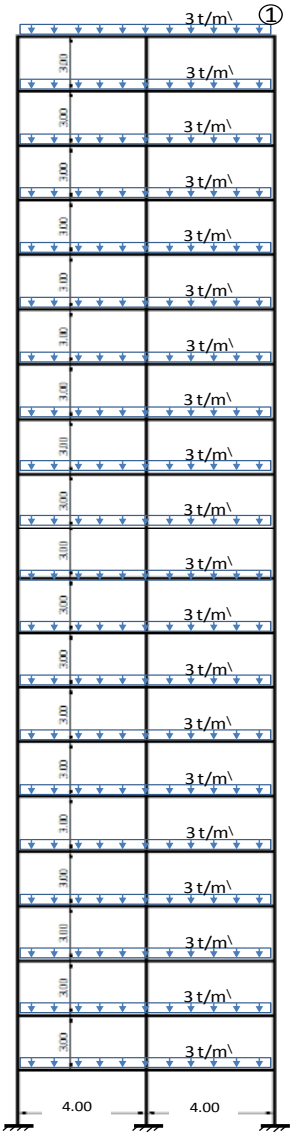

20- stories model

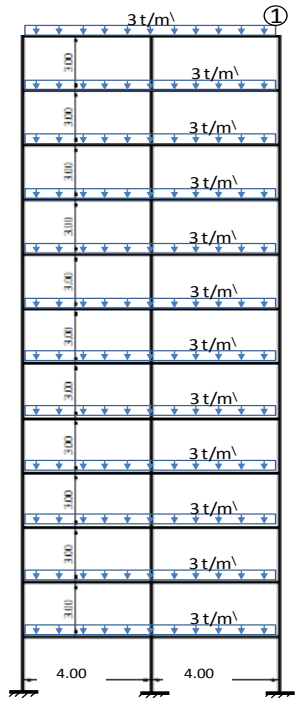

12- stories model

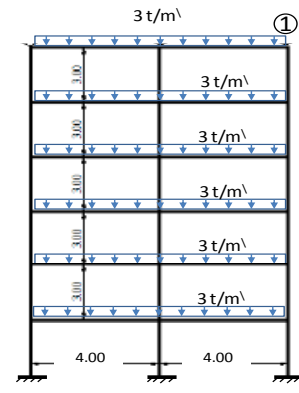

6- stories model

Fig. 2. geometry and dimensions of tested models

Where; Joint (1) represents the top displacements of each frame.

Journal of Engineering Sciences, Assiut University, Faculty of Engineering, Vol. 41, No. 5, September, 2013,E-mail address: jes@aun.edu.eg 
M. N. Mohamed, et al., Evaluation of Current Egyptian Code on Seismic Behavior of Multi-Storey Buildings, pp. 1743 - 1752

\section{Loads}

The applied load on the beams of the two dimensional models is assumed to be $=3 \mathrm{ton} / \mathrm{m}$.

In the traditional method that is accredited by Egyptian code (201/2008), the dynamic loads that result from the effect of earthquake were represented as horizontal forces affecting the models at each floor level as given in equation 2.

While in time history method, real El-Centro earthquake wave (Fig. 3) was used, assuming the value of earthquake acceleration $=0.5 \mathrm{~g}$.

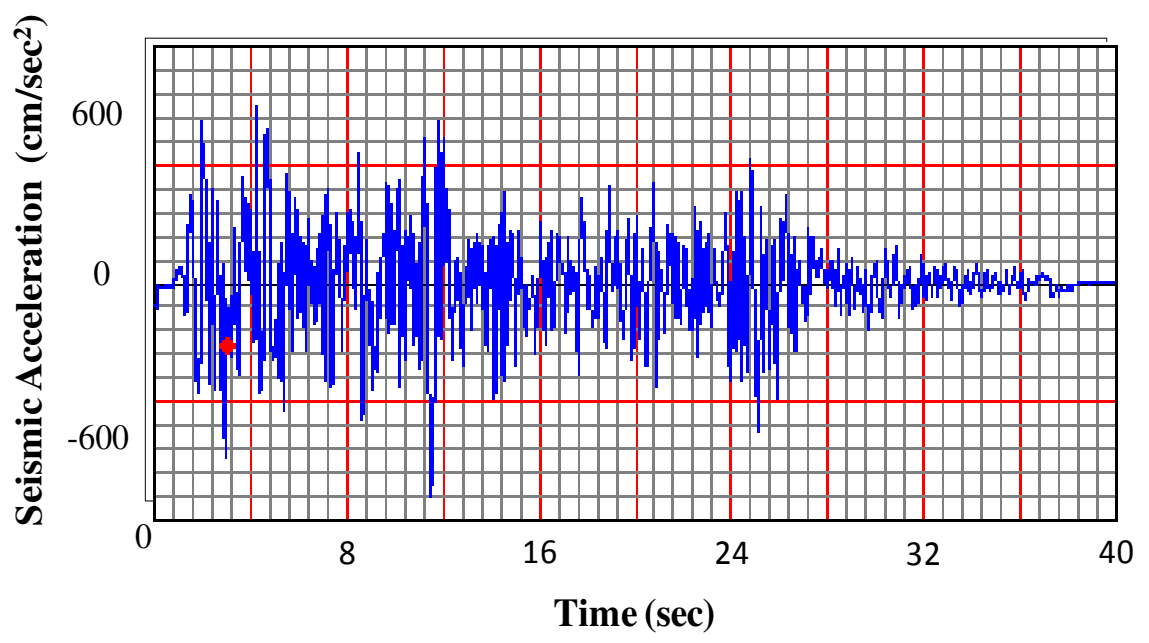

Fig. 3. El-Centro earthquake wave

\section{Results \& Discussions}

In this part, the structural seismic behavior was investigated by two methods (Egyptian code method and time history method) to determine the effect of columns stiffness and stories number on both values of base shear and top displacements separately.

\section{1. Base shear}

Fig. 4 illustrates the relationship between number of stories versus base shear for different column cross sections calculated using time history method (T.H). Another curve is plotted on the same figure using solid line shows the same relation for the traditional code method which neglects the effect of columns cross sections. 
M. N. Mohamed, et al., Evaluation of Current Egyptian Code on Seismic Behavior of Multi-Storey Buildings, pp. 1743 - 1752

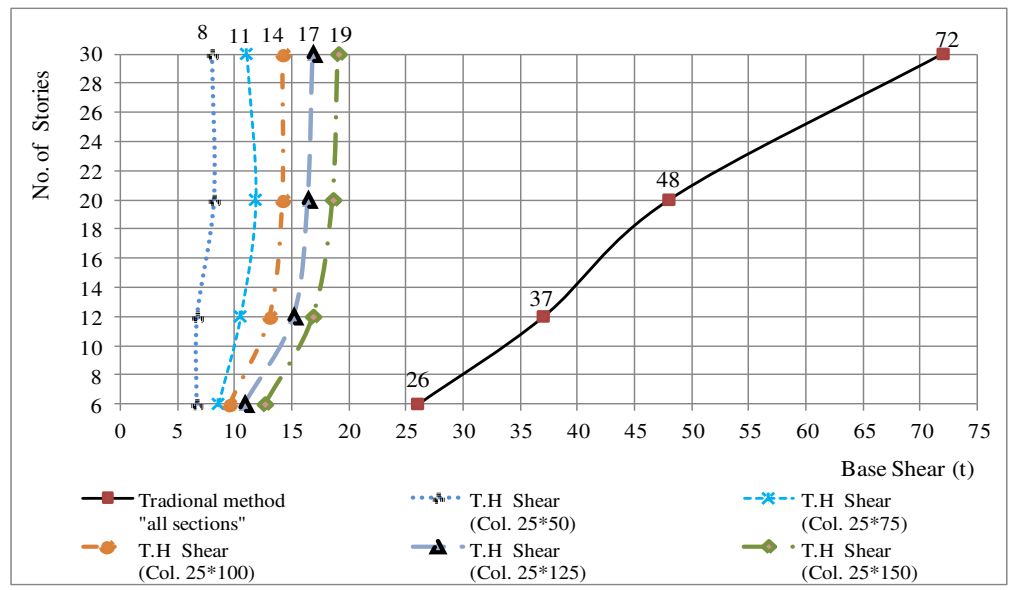

Fig. 4. the relationship between sum of resultant base shear against stories number for various column cross sections

From figure 4, the following points are noticed:

- Regarding to Traditional code curve (solid curve):

- The value of base shear significantly increased by increasing number of floors in an approximate linear relationship, as stated below:

- The increasing rate in the value of base shear in case of increasing number of stories from 6 to 12 stories $=42.3 \%$

- The increasing rate in the value of base shear in case of increasing number of stories from 12 to 20 stories $=29.7 \%$

- The increasing rate in the value of base shear in case of increasing number of stories from 20 to 30 stories $=50 \%$

- It is clear that the code curve has not taken into account the variation of columns cross sections as the code equation itself neglects this influence completely.

\section{- Regarding to time history curves ( 5 dotted curves):}

- The base shear value varies with both, column cross section (Stiffness) and number of stories.

- The changing rate in the value of base shear in case of increasing number of stories from 6 to 12 stories ( $26.7 \%$ in average) is higher than the increasing rate between 12 and 20 Stories ( $12.4 \%$ in average), while the changing rate in the base shear in case of increasing number of stories from 20 to 30 is the smallest rate $(2.8 \%$ in average). So it was monitored that, the changing rate in base shear between stories reduced clearly when increasing number of stories above 20 stories, and achieved very small values between 20 and 30 stories models. This is in contradiction with the adapted approach from Egyptian code.

Journal of Engineering Sciences, Assiut University, Faculty of Engineering, Vol. 41, No. 5, September, 2013, E-mail address: jes@aun.edu.eg 
M. N. Mohamed, et al., Evaluation of Current Egyptian Code on Seismic Behavior of Multi-Storey Buildings, pp. 1743 - 1752

- The change in base shear is affected by increasing the column cross sections but the average increasing rates in the base shear are decreased by increasing column cross section as follows:

- $41 \%$ in case of increasing column cross section from $25^{*} 50$ to $25^{*} 75$

- $21 \%$ in case of increasing column cross section from $25^{*} 75$ to $25^{*} 100$

- $16 \%$ in case of increasing column cross section from $25^{*} 100$ to $25^{*} 125$

- $14 \%$ in case of increasing column cross section from $25 * 125$ to $25 * 150$

\section{- Comparing the results of traditional code method and time history method, the} following points can be concluded:

- It is clear that, columns stiffness has a significant influence on base shear values when using time history method, while it has no effect at all if traditional code approach is used.

- Time history and traditional methods are influenced by number of stories, in general by increasing number of stories the base shear value increases, but the base shear value and its rate of change differ between both methods, higher in traditional code method and lower in time history method.

- There is a significant difference between the base shear value results from time history and traditional code methods. This difference is clarified in the stated example below for column cross section $(25 * 150)$ :

- For 6 stories model, percentage of base shear by traditional code method compared to corresponding value by time history $=206 \%$

- For 12 stories model, percentage of base shear by traditional code method compared to corresponding value by time history $=220 \%$

- For 20 stories model, percentage of base shear by traditional code method compared to corresponding value by time history $=258 \%$

- For 30 stories model, percentage of base shear by traditional code method compared to corresponding value by time history $=378 \%$

- From the above discussion it is clear that, the percentage of base shear by traditional code method compared to corresponding value by time history, increased by increasing number of stories.

\section{2. Top displacement}

Fig. 5, shows the relationship between top displacements of the upper joint 1 clarified in fig. 2 (resulted from both time history method (T.H) and code method) and number of stories for different columns stiffnesses. Solid lines represent the results of traditional code method.

Journal of Engineering Sciences, Assiut University, Faculty of Engineering, Vol. 41, No. 5, September, 2013, E-mail address: jes@aun.edu.eg 
M. N. Mohamed, et al., Evaluation of Current Egyptian Code on Seismic Behavior of Multi-Storey Buildings, pp. 1743 - 1752

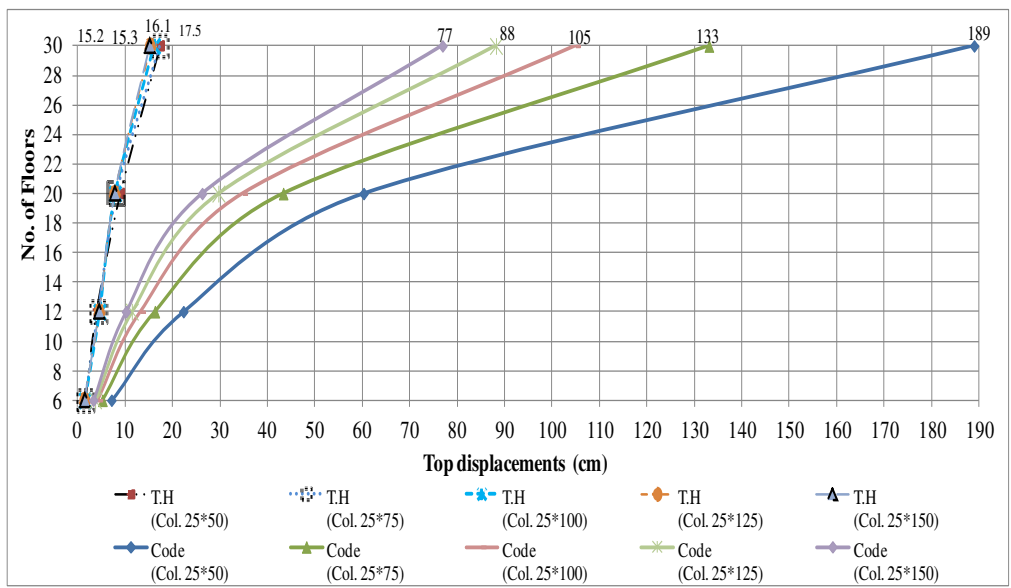

Fig. 5. the relationship between top displacements against stories number - for various column cross sections

From figure 5, the following points are clearly noticed:

- The change in column cross section has a very slight effect on top displacements values by using time history analysis, the average decreasing in top displacements values when increasing columns stiffness (increasing the column cross section from $25 * 50$ up to $25 * 150$ ) is $3.7 \%$, while such change has a magnificent influence if code equations are used (the maximum decrease in top displacement value when increasing column cross sections from $25 * 50$ to $25 * 150$ concerning 30 stories $=145.5 \%$ ).

- The rate of increase in top displacement is tangible by increasing the number of stories in time history analysis ( $85 \%$ when increasing number of stories from 12 to 20 for all column cross sections), while this rate of increase is magnificent if code equations are used (163\% when increasing number of stories from 12 to 20 for all column cross sections).

\section{Table 2.}

illustrates the percentages of top displacements for each column cross section using code equations compared to corresponding values by time history analysis,

\begin{tabular}{|c||c|c|c|c|c|}
\hline Number of stories & $\begin{array}{c}\text { Col. Section } \\
25 * 50\end{array}$ & $\begin{array}{c}\text { Col. Section } \\
25 * 75\end{array}$ & $\begin{array}{c}\text { Col. Section } \\
25 * 100\end{array}$ & $\begin{array}{c}\text { Col. Section } \\
25 * 125\end{array}$ & $\begin{array}{c}\text { Col. Section } \\
25 * 150\end{array}$ \\
\hline 6 stories & $410 \%$ & $328 \%$ & $285 \%$ & $248 \%$ & $216 \%$ \\
\hline 12 stories & $544 \%$ & $374 \%$ & $289 \%$ & $250 \%$ & $224 \%$ \\
\hline 20 stories & $661 \%$ & $530 \%$ & $441 \%$ & $380 \%$ & $334 \%$ \\
\hline 30 stories & $1079 \%$ & $770 \%$ & $651 \%$ & $575 \%$ & $506 \%$ \\
\hline
\end{tabular}

It is clear from the above table that, the percentages of top displacements using code equation compared to corresponding values by time history analysis, increased by decreasing column

Journal of Engineering Sciences, Assiut University, Faculty of Engineering, Vol. 41, No. 5, September, 2013,E-mail address: jes@aun.edu.eg 
M. N. Mohamed, et al., Evaluation of Current Egyptian Code on Seismic Behavior of Multi-Storey Buildings, pp. 1743 - 1752

cross section (stiffness). Also it is clear that there are magnificent differences between top displacements resulted from code method and time history method.

\section{Conclusions}

From the presented study the following important findings are drawn out:

- In the traditional code method as given by Egyptian code (201/2008),

- The value of base shear significantly increased by increasing number of stories in an approximate linear relationship, but column stiffness has no effect at all on the base shear value.

- The value of top displacements shows magnificent increase by increasing both number of stories and column stiffness.

- Regarding to time history method,

- The change in column cross section has a tangible effect on base shear value and a very slight effect on top displacements values

- The rate of change in base shear value is tangible up to 20 stories, while this rate is small (2.8\% in average) for numbers of stories 30 referred to 20 stories. Therefore it can be stated that, after a certain number of stories ( 20 stories in this study) there is no considerable change in the base shear.

- The rate of increase in top displacement is tangible to some extent by increasing number of stories.

- Comparing the results of traditional code method "as given by Egyptian code (201/2008)" and time history method, the following points can be concluded:

- The column stiffness factor influence is well considered when using time history method and neglected at all if traditional code method is used.

- Time history and traditional methods are influenced by number of stories, in general by increasing number of stories the base shear value increased, but the base shear value and its rate of change differ between both methods, higher in traditional code method and lower in time history method.

- There is a significant difference between time history and traditional code methods in the base shear value, as example, for case study column cross section $25^{*} 150$ as an example, average percentage variation of base shear by traditional code method compared to corresponding value by time history is $265 \%$ in average.

- Top displacement values are magnificently higher in traditional code approach compared to the same values obtained by time history method (in average this difference reaches $455 \%$ ).

- Based on the above results, this research proved that the column stiffness is an important factor that has significant influence on calculating base shear and top displacements values. However, the Egyptian code (201/2008) neglects the effect of column stiffness in calculating base shear, leading to high base shear values and top displacements so far from the actual behavior. Furthermore the parameter of number of stories leads to nonrealistic results in the traditional code approach compared to the exact behavior obtained from applying the time history analysis; those overestimated values of base shear and top displacement lead to uneconomic design. Therefore, this

Journal of Engineering Sciences, Assiut University, Faculty of Engineering, Vol. 41, No. 5, September, 2013,E-mail address: jes@aun.edu.eg 
M. N. Mohamed, et al., Evaluation of Current Egyptian Code on Seismic Behavior of Multi-Storey Buildings, pp. 1743 - 1752

study strongly recommends that such important parameters (column stiffness and realistic effect of number of stories) should be taken into account in computing the lateral seismic forces acting on a multi-story building in the Egyptian code.

\section{References}

[1] Chen, W. F. and Lui, E.M.: Earthquake engineering for structural design, CRC press. Taylor and Francis Group, 2006.

[2] Egyptian Code (201) for calculating Loads and forces for Construction Works, Research Center for Housing and Construction, Ministry of Housing, Utilities and Urban Planning, Cairo, Egypt, 2008.

[3] M. Ahmed, M. K Dad Khan and M. Wamiq: Effect of concrete cracking on the lateral response of RCC buildings, Asian journal of civil engineering (building and housing) Vol. 9, No. $1,2008$.

[4] SAP2000 Analysis Reference, Volume 1, Computers and Structures, Inc.,Berkeley, CA, 1997.

[5] Wai-Fah Chen : Earthquake Engineering Handbook, Hawaii University, Charles Scawthorn, 2003.

\section{تقييم الكود المصرى فى حساب التأثير الزلزالى على المنشآت متعددة الأدوار}

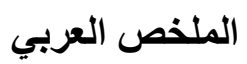

الكود المصري يحتوى على صيغة لإيجاد قيمة القص القاعدي المؤثر على المنشأت متعددة الطوابق نتيجة التأثير

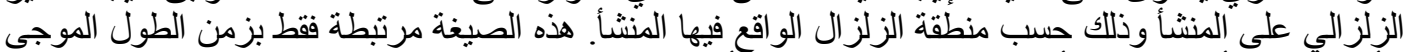

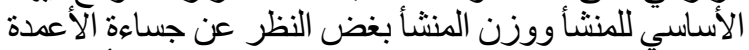

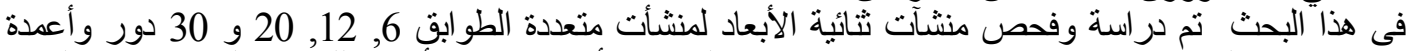

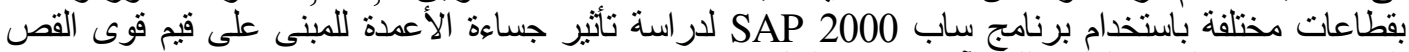

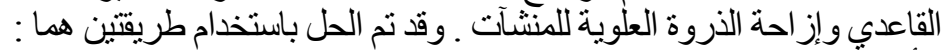
الأولى:الطريقة التقليدية التقريبية التى بنص علية التيها الكود المصري لحساب الأحمال والقوى فى الأعمال الإنشائية وأعمال المباني 2008/201

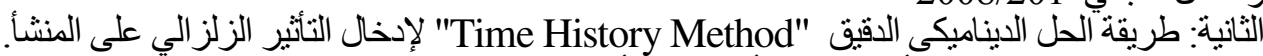

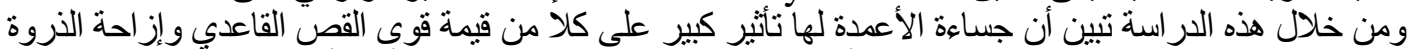

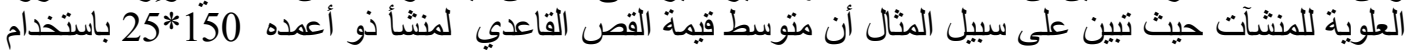

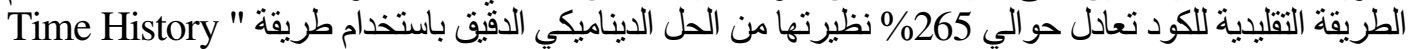
Method

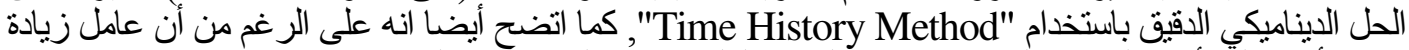

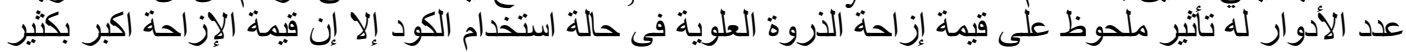

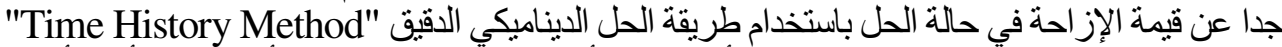

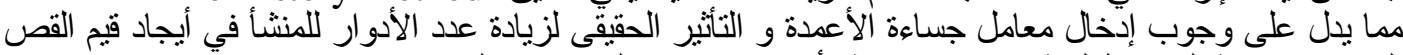

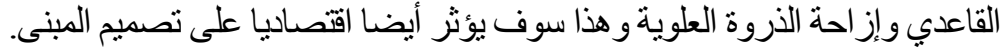

Journal of Engineering Sciences, Assiut University, Faculty of Engineering, Vol. 41, No. 5, September, 2013, E-mail address: jes@aun.edu.eg 